\title{
The GOP's Radical Assault on Regulations Has Already Begun
}

Three bills awaiting Senate approval would go a long way to achieving Steve Bannon's dream of the "deconstruction of the administrative state."

by Peter Shane_http://washingtonmonthly.com/people/peter-shane//

February 27, 2017

ongressional Republicans and the Trump administration appear to share a straightforward
philosophy on regulatory reform: "regulation bad, deregulation good." Presidential adviser Steve Bannon, speaking at the Conservative Political Action Conference this week, said one of the administration's three top priorities is the "deconstruction of the administrative state."

Three radical bills already passed by the House of Representatives, and awaiting approval by the Senate, show how Bannon could get his wish. It is harder to put a human face on this agenda than on the Trump travel ban, but it is just as perverse. Many decades of executive-legislative collaboration have resulted in thousands of regulations that help to safeguard the environment, manage the economy, protect students, workers, and consumers against discrimination, and much more. No doubt some regulations can be usefully updated or even repealed, but modern life is unimaginable without the protections of government regulation.

To perceive the radicalism of the new statutes, keep in mind that most federal regulations already run a demanding gauntlet of scrutiny. First, an agency can make a binding rule only if Congress has passed a statute directing or permitting it to do so. (For example, air-pollution regulations are authorized by the Clean Air Act.) When an agency wants to issue a new regulation, it must gather facts, consult with potentially affected parties, give the public an opportunity for input, assess costs and benefits (which are often reviewed in the Office of Management and Budget), and craft both a final rule and an explanatory 
statement-sometimes book-length-that accounts for all that went before. A year's passage between initial proposal and final rule is not unusual and even fairly efficient. If a regulation is challenged in court, the process will stretch on much longer.

The three new bills passed by the House take aim at this process in two ways. On the front end, the GOP wants to make the process of passing new regulations even longer and more painstaking. Under the Regulatory Accountability Act, the gauntlet of required analyses and public notices for new rules would become vastly more complex, even requiring something like a formal trial for some suggested regulations. Meanwhile, one section of the Regulations from the Executive in Need of Scrutiny, or REINS Act, would essentially convert "major rules" into mere proposals to Congress. Even though an earlier Congress had authorized an agency to make rules, the current Congress would have to take a second vote to make the output of the agency's regulatory process legally binding.

But it's what the new legislation does to the back end of the administrative process-accelerating the repeal of existing regulations-that is most alarming. Under another section of the REINS Act, every year for the next decade, each administrative agency that issues regulations would have to submit ten percent of its existing rules to be approved by Congress. In just ten years, Congress could eliminate virtually all federal regulations simply by never holding votes on whether to keep them in place. This decade-ofdestruction provision is so extreme that one has to wonder if it was added to the bill just to make other destructive GOP ideas seem reasonable by comparison.

For example, another House-passed bill, the Midnight Regulations Relief Act (MRRA), would expand Congress's fast-track ability at the beginning of each session to revoke regulations issued in the latter half of the prior year. Under existing procedures, Congress can already scuttle any Obama Administration regulation issued on or after June 13, 2016, by enacting a joint resolution that is not subject to protracted committee review or a Senate filibuster, and which automatically prohibits the agency from ever reproposing a "substantially similar" rule. The only limit is that a joint resolution of disapproval can revoke only one regulation at a time. Discussions and votes at least have to be focused, and the public can eventually determine who voted for and against specific policies. The MRRA would do away with that limitation, so that a joint resolution of disapproval could include an unlimited number of rules from the end of the last President's term.

As the name suggests, Republicans present the bill as a way to counteract last-minute regulations jammed through by a president on his way out the door. But that is deeply misleading because these socalled "midnight" regulations are only finalized in the last six months of a term; most are actually the product of years deliberation and analysis. A perfect example is the Stream Protection Rule, designed to 
keep runoff from surface mining out of America's waterways. Although it took effect as a final rule on President Obama's last day in office, it emerged from a process of analysis, public comment, and deliberation that started almost as soon as Obama took office eight years earlier.

In November 2009, the Department of the Interior published an "advance notice of proposed rulemaking," which described ten plausible alternative approaches "to significantly reduce the harmful environmental consequences of surface coal mining operations in six Appalachian states." The Department then took over five years to analyze nearly 33,000 public comments and analyze the environmental and regulatory impact of the alternatives. The final rule didn't emerge until December 2016, intended to take effect a month later.

Yet using its fast-track process, Congress voided eight years of work in just three days, January 31 through February 2, 2017, without any hearings or committee deliberation whatsoever. The disapproval was debated for an hour in the House and for portions of two days' business in the Senate. If the MRRA were enacted, dozens of major rules on subjects as diverse as environmental protection, food labeling, the employment practices of federal contractors, and performance standards for federally funded school programs could be scuttled through a single legislative act. Republicans in the House have already introduced more than two dozen individual resolutions of disapproval.

The two approaches embodied in these statutes-requiring more deliberation before making new regulations, but less deliberation to get rid of old ones-may seem contradictory. But what links them together is the Republican article of faith that regulations are presumptively bad. If you accept that, then of course you should want to make it as hard as possible to make new regulations and as easy as possible to get rid of ones that already exist.

\section{Neither the unending regulatory labyrinth that Republicans propose to erect, nor faster glide paths to regulatory deconstruction, would represent a serious pursuit of the public welfare.}

In a way, the oddest of all the "reform" proposals is "cut-go," a blend of ambitions to both stymie new rulemaking and eliminate old rules. One section of the REINS Act would require that, before an agency could implement a new regulation, it would have to figure out how to repeal enough existing regulations so that the net social cost of implementing the new rule would be zero. The glaring problem with this 
approach is that the two halves of the exercise-adopting a new regulation and repealing an existing one -logically have nothing to do with one another. Why should taking one step to protect health and safety come at the cost of abandoning another?

Yet President Trump, unwilling to wait for congressional authorization, has incorporated his own version of cut-go into an executive order that directs agencies to implement it "unless prohibited by law." The order would require for the current fiscal year that the rules chosen completely offset incremental costs of new regulation. OMB could relax this requirement in the future-suggesting that the driving point for Trump is not to save money, but simply to boast that his administration will be ditching twice the number of rules that it adopts.

Fortunately, unless the Senate approves something like the REINS Act, the Trump executive order cannot legally be implemented, just as a lawsuit recently filed in federal court by Public Citizen, the Natural Resources Defense Council, and the Communications Workers of America argues. When Congress directs an agency to issue regulations to address a particular problem, the factors that legally count as "relevant" include issues Congress itself identifies for agency concern and any other factors logically relevant to implementing the statute at hand. In other words, the factors an agency may consider in deciding how to regulate under the Clean Air Act would be logically related to limiting air pollution.

What isn't legally relevant in evaluating a new proposed regulation is whether there are two old ones available to trash. There is no regulatory statute authorizing any agency to take that into account. (The same is true of another misguided process the order would impose, a regulatory budget.) An agency explaining that its repeal of Rule A was necessary to secure OMB approval to promulgate Rule B would be laughed out of court. Trump's order raises the puzzling question whether a presidential command, in effect, to ignore the law "unless prohibited by law" is lawful. Of course, if the cut-go provision of the REINS Act makes it through the Senate, then agencies really will have to perform this nonsensical routine every time they try to carry out their mission.

Neither the unending regulatory labyrinth that Republicans propose to erect, nor faster glide paths to regulatory deconstruction, would represent a serious pursuit of the public welfare. The blunt agenda is just anti-regulatory ideology masked as reform. In every field of regulation, there is room for making existing rules more cost-effective and eliminating those that have outgrown their usefulness-just as there are areas of risk to the environment, to the financial system, and to the quality of our public sector to which government has not attended enough. But improving regulation should be systematic, not arbitrary, and guided by public interest goals. GOP regulatory reform and its determined obliviousness to 
the benefits of good regulation portend enormous harm. The details of public administration can be obscure, even tedious, but it is critical that regulatory benefits not be sacrificed at the altar of antiregulatory dogma.

Peter Shane_http://washingtonmonthly.com/people/peter-shane/)

Peter Shane teaches constitutional law at the Ohio State University's Moritz College of Law and is the author of

Madison's Nightmare: How Executive Power Threatens American Democracy_http://www.amazon.com/madisonsnightmare-executive-threatens-democracy/dp/0226749398)

(University of Chicago Press 2009).

(c) 2017 Washington Monthly. 